\title{
QUALITY MANAGEMENT CONCEPT AND COMPETITIVENESS OF SERBIAN COMPANIES
}

\author{
Dejan ĐORĐEVIĆ ${ }^{1}$, Dragana SAJFERT ${ }^{2}$, Bojana GLIGOROVIĆ ${ }^{3}$ \\ ${ }^{1}$ University of Novi Sad, Technical faculty "Mihajlo Pupin” in Zrenjanin, 23000 Zrenjanin, Djure Djakovica bb, \\ Republic of Serbia. \\ ${ }^{2}$ Ph.D. Student, University of Novi Sad, Technical faculty "Mihajlo Pupin” in Zrenjanin, 23000 Zrenjanin, Djure \\ Djakovica bb, Republic of Serbia. \\ ${ }^{3}$ University of Novi Sad, Technical faculty "Mihajlo Pupin" in Zrenjanin, 23000 Zrenjanin, Djure Djakovica bb, \\ Republic of Serbia. E-mail: bojana@tfzr.uns.ac.rs
}

Accepted 1 November, 2013

\begin{abstract}
Serbian economy has experienced problems with productivity for a long time. It was the result of inappropriate way of business performance which was not based on market principles. Certain products had unjustifiably high prices which were not competitive on the world market. Technological equipment also represents a significant element of productivity rising. If Serbian companies want to achieve competitive advantage on the global market, they should change the way of thinking ad adopt modern world achievements in the field of organization management. In this paper the authors analyse the aspects of business excellence positioning in relation to improving quality of company's business and achieving sustainable competitiveness of national economy.
\end{abstract}

Keywords: Competitiveness, Productivity, Quality, Management, Business Excellence.

\section{INTRODUCTION}

Global economy requires from companies which participate in the market competition to invest significant efforts directed towards creation of new business strategies. New business conditions require implementation of new business models. World economic crisis from 2008 emphasized the necessity of creating new models of business. Ohmae (2007) thinks that global economy is based on the world in which the absence of boundaries is not a dream or a possibility, but a reality. Global economy has its own dynamics and logics because it is not a theory any more but a reality, in fact. The stress is on knowledge because success and a very survival depend on the ability to accept new attitudes and relations with the world.

Beside their structure, enterprises have to change the aim of their business as well. In a long term view a customer is in focus of organization's attention as well as different interest groups from the surroundings whose requirements have to be noticed and satisfied. Quality and productivity represent the elements for establishing global competitive position. Knowledge becomes a product and corporative intellectual property is nowadays more valuable than physical resources.

\section{NATIONAL COMPETITIVE CAPACITY AND GLOBAL ECONOMY}

Opening the economy causes the necessity to face up competition on the international market. Specialist literature provides various definitions concerning competitiveness of national economies, (Porter, 1990; Thompson, 2003, 2004). As regards to international competitiveness, it is also referred to a wider notion - competitive capacity, which is evaluation of development potential of a country or enterprise and it does not only refer to real perspective but rather to subjective one, i.e. concerning quality, organization and management and ability of the subject to assume effective development strategy. At the same time, at present, factors which are to a large extent non-material determine competitive capacity of the country. Therefore, many factors shape country's competitive capacity, which apart from system conditions is dependent on the factors connected with broadly defined human capital and innovation as well as entrepreneurship. 
Accordingly, it can be said that the following aspects are decisive as regards to international competitive capacity of domestic economy, (Kefela, 2010; Yu and Wang, 2010): human resources including skills, resources and effectiveness of using natural resources, physical capital, which also depends on the level of development and effectiveness of using technical knowledge, efficiency of social and economic system including economic policy. Indices of international competitiveness (competitive capacity) consist of the ones concerning economic development of the country, inter alia, GDP growth rate and also synthetic indices might be distinguished.

Market globalization, rise of newly industrialized countries and particularly the effects of World economic crisis have established new competitive relations on the world market. The World economic crisis has influenced the change in behaviour of enterprises considering their competitive ability maintenance. Majority of applied measures was reduced to cost reduction in the function of keeping productivity level and making strategic partnerships, but the question of price competitiveness has become the focus again although it was neglected for some time. New business conditions ask for new comprehension of competitiveness. Transitional countries are also hit by economic crisis especially considering withdrawing quality investors or freezing current investments.

The current moment of global economy is characterized by slow but secure rise of enterprises from newly industrialized countries such as China, India, Brazil, South American countries, etc. Enterprises from these countries are becoming global competitors. Their competitive ability is based on lower costs of business particularly because of lower labor costs but also for their openess towards foreign investments and acceptance of most modern methods and techniques of management. The main stimulus in these economies is increased domestic consumption. Although during 2011 and 2012 there was a partial slowdown of economic growth in these countries, especially in China, these countries will have a significant role in global economy in the near future. It is still obvious that two Asian cities, Shanghai and Mumbai, economic centers and magapolis, will be two most developed cities in the world about 2030.
New business conditions require adjustement of business entities and building organizational structure based on these new postulates. This is especially important for enterprises from transitional countries - the final aim of building a new organization is that it becomes extremely flexible and innovative, in other words, that it becomes able to satisfy more and more demanding requirements of customers in shorter period of time and also to make competitive advantage which involves emotional component as well. Quality, product diferentiation and integrated marketing communication represent a key element for making a successful trade mark with stable market position. Quality is becoming a primary development aim materialized through achieving business excellence and top class of products and services.

Based on the available data about competitiveness for 2012 shown in Table 1, it can be noticed that among the first ten most competitive countries in the world are dominating North European countries (Finland, Sweden, Netherlands, Germany and Great Britain) as well as the Pacific region countries (Singapore, Hong-Kong, Japan). Switzerland has retained the first place while USA fell two places and this trend will probably continue. According to the list of World Economic Forum for 2012, China takes 29th place comparing to its 26th place in 2011. On the other hand, Singapore, Hong-Kong and Taiwan (13th place) are under Chinese market influence (technological and investment connection of these markets). Brazil takes 48th place (53rd in 2011), India is 59th (56th in 2011), Russia is 67th (66th in 2011).

On the other hand, some authors talk about redefinition of global strategy (Table 2), considering the change of competitive relations and longlasting influence of the World economic crisis on business. Redefinition of global strategy is the process consisting of five steps:

1. Revision of realization,

2. Analysis of industry and competitiveness,

3. Analysis of differences - CAGE form of distance (CAGE - cultural, administrative, geographic, economic, in other words, analysis of cultural, administrative, geographic and economic factors which determine mutual difference among the markets),

4. Development of strategic options AAA (Adapttion, Agregation, Arbitration),

5. Estimation - ADDING score list of values, (Ghemawat, 2010). 
Table 1. Ranking of the first 10 countries in the world according to their competitiveness in 2012 (The Global Competitiveness Report 2012-2013)

\begin{tabular}{|l|c|c|}
\hline \multicolumn{1}{|c|}{ Country } & $\begin{array}{c}\text { Place 2012- } \\
\text { 2013 }\end{array}$ & $\begin{array}{c}\text { Place 2011- } \\
\text { 2012 }\end{array}$ \\
\hline Switzerland & 1 & 1 \\
\hline Singapore & 2 & 2 \\
\hline Finland & 3 & 4 \\
\hline Sweden & 4 & 3 \\
\hline Holland & 5 & 7 \\
\hline Germany & 6 & 6 \\
\hline USA & 7 & 5 \\
\hline Great Britain & 8 & 10 \\
\hline Hong Kong & 9 & 11 \\
\hline Japan & 10 & 9 \\
\hline
\end{tabular}

Table 2. Instruments of global strategy (Ghemawat, 2010)

\begin{tabular}{|l|l|l|}
\hline $\begin{array}{c}\text { ADAPTATION - } \\
\text { ADAPTATION TO } \\
\text { DIFFERENCES }\end{array}$ & \multicolumn{1}{|c|}{ OVGRECOMING DIFFERENCES } & \multicolumn{1}{c|}{$\begin{array}{c}\text { ARBITRATION - } \\
\text { USING DIFFERENCES }\end{array}$} \\
\hline Variation & Regions & Cultural \\
\hline Focus & Other grouping of countries & Administrative \\
\hline Relocation & Grouping other than according to countries & Geographic \\
\hline Design & Business or product & Economic \\
\hline Innovation & Global client & \\
\hline & Industries of clients & \\
\hline & Channel & \\
\hline
\end{tabular}

Every top manager of a company which has an ambition to make value overborder should be able to conclude which of three A will be base for overborder competitive advantage of the company. General advice in relation to AAA strategies is to determine firmly merely one of A strategies and then on the grounds of it to search the next one, but paying attention not to neglect implementation of triple strategy.

Although competitiveness and innovation is present in every debate on regional development policies, South East Europe is rarely associated with those two terms, (Will, 2006). However, the cooperation area is undergoing fundamental changes in economic and production patterns after the 1990 changes. Some regions, especially capital cities are adapting well to the new challenges, others are trying to re-orientate themselves to find the right strategies for catching the opportunities of the global market. The EU has developed various forms of cooperation with the nearby countries, which are not non-EU countries. Experience acquired during successive enlargements shows that integration process will be still deepening since a large extent of political borders constitutes a barrier for further enlargement of membership rather than geographical ones. Integration processes will influence competitive capacity of the country, causing implications for domestic economies through structural adjustments which take place, (Muldur et al., 2006; Stajano, 2009). All the same, a long period of integration with the EU might be a positive factor for these economies of South-Eastern European Regions; it might be favourable for their economic growth and influence their competitive capacity. The necessity of strengthened regional cooperation, which could constitute an element of stabilization in this area, gives the possibility of settling the existing common problems, (European Commission, 2012).

Significant indicator of developed competitiveness of national economies in modern global framework represents the establishment of Sustainable Development Strategy (SDP). In South-Eastern European countries there has been a rapid emergence of SDP since 2007 as part of the development of the National Strategy for Sustainable Development (NSSD) - in particular in Croatia, Serbia, Macedonia and Montenegro, (United Nations Economic Commission for Europe, 2012). The NSSDs of Croatia and Serbia include indicators for sustainable consumption and production. 


\section{SERBIAN COMPANIES - QMS AND COMPETITIVENESS}

The companies coming from transitional countries in general, and Serbia among them, have problems with quality of their business and production productivity. Inherited inefficient production system, as well as transitional recession common for all countries in transition, influence these companies and may be blamed for their insufficient competitive capacity. Serbian companies have been uncompetitive on international market for a long period of time. Low productivity and insufficient investment in achieving business quality are the main reasons for poor competitiveness of domestic companies. This insufficient competitive ability has become more visible upon appearing the world economic crisis. The problem is especially obvious in the companies dominated by autochthonous private capital. The reason for relatively small number of
Serbian companies that implemented quality system can be found in difficult financial situation of domestic economy and the implementation of QMS asks for considerable business efforts on the side of companies. What concerns most is the fact that almost all big companies have already implemented QMS. On the other hand, the majority of all companies in Serbia are made from SMEs $(90 \%)$.

According to the list of World Economic Forum for 2012, Serbia took 95th place out of 144 analyzed countries. Since Serbia took 95th place in 2011 and 96th in 2010 it is obvious that there is no progress in competitiveness. It is interesting that Serbia found itself between Argentina (94th place) and Greece (96th place). Table 3 shows the ranking of ex-Yugoslav countries in the last five years, according to WEF, (The Global Competitiveness Report 2012-2013).

Table 3: Ranking of West Balkan countries according to their competitiveness in the period 2008-2012

\begin{tabular}{|l|c|c|c|c|c|}
\hline Country & $\begin{array}{c}\text { Place } \\
\text { in 2008 }\end{array}$ & $\begin{array}{c}\text { Place in } \\
\text { 2009 }\end{array}$ & $\begin{array}{c}\text { Place } \\
\text { in 2010 }\end{array}$ & $\begin{array}{c}\text { Place } \\
\text { in 2011 }\end{array}$ & $\begin{array}{c}\text { Place } \\
\text { in 2012 }\end{array}$ \\
\hline Slovenia & 42 & 37 & 45 & 57 & 56 \\
\hline Montenegro & 65 & 62 & 48 & 60 & 72 \\
\hline Croatia & 61 & 72 & 77 & 76 & 81 \\
\hline Macedonia & 89 & 84 & 79 & 79 & 80 \\
\hline Serbia & 85 & 93 & 96 & 95 & 95 \\
\hline BH & 108 & 109 & 102 & 100 & 88 \\
\hline
\end{tabular}

Considering the countries from near surroundings, Hungary takes 60th place, Bulgaria 62nd, Romania 78th, Albania 89th place. It is obvious that the effects of the World economic crisis have influenced the fall of competitiveness in all countries from the region. Taking into account the fact that Bosnia and Herzegovina improved its position on the list we can conclude that Serbian economy is the most uncompetitive in the region of West Balkans as well as in South East Europe.

According to the business conditions list made by Forbes journal, Serbia takes 93rd position out of 134 countries and the fall comparing to the last year is significant (81st place) - Table 4 .

Old technology, poor quality, unattractive packaging and high prices are the main reasons for uncompetitiveness of Serbian products. Least competitive is manufacturing industry, metal industry and electronics, in which for years there has been no technological reconstruction. Business people think that it is necessary to make customs and tax examptions, reduction of administrative levies as well as prices for electrical energy, gas and fuels in order to increase competitiveness. It is also necessary to rise the level of technological facilities because the average age of machines in Serbia is 30 years. Comparing to the region it is a delay of 12 years, (Đorđević et al., 2011).

\section{Table 4: Position of Serbia according to individual criteria defining}

business conditions (Forbes, 2011)

\begin{tabular}{|l|l|}
\hline Criterion & Rank \\
\hline Monetary freedom & 118 \\
\hline Innovations & 114 \\
\hline Property right & 106 \\
\hline Tax burden & 100 \\
\hline Trade freedom & 90 \\
\hline Technology & 67 \\
\hline Corruption & 66 \\
\hline Investors protection & 59 \\
\hline Personal freedom & 42 \\
\hline
\end{tabular}


New business conditions demand a new approach to business performance of domestic companies. Old fashioned methods and techniques of management have to be abandoned and modern empirical and practical achievements applied along with permanent education of executives and other employees. A special attention should be paid to building a new organization.

In order to achieve market success a company should have competitive advantage in the form of lower costs and/product differentiation, a strategy of long term ensuring of high quality products and services and permanent innovations. Companies should take efforts in order to satisfy requirements of more and more educated and informed customers.

The research results (it dealt with the analysis of attitudes of young people related to their involvement in entrepreneurial process as well as with their comprehension about success of business practice in domestic companies) represent opinions of future experts and executives. The research has been carrying out for three years in a row (2010-2012) on the territory of Republic of Serbia in 16 towns and municipalities - Beograd, Bačka Palanka, Novi Sad, Subotica, Požarevac, Kragujevac, Šabac, Kraljevo, Čačak, Ivanjica, Sremska Mitrovica, Paraćin, Zrenjanin, Alibunar, Niš and Jagodina, during November and December. The survey is carried out by questionnaire. The population is built on students from four universities and business schools. It includes almost 2000 students directed towards business and management. The average age of examinees is about 22 years. Around $38 \%$ men and $62 \%$ women participate in the sample. The research from 2012 was the most extensive and it involved 755 students. Considering evaluation of competitive ability of domestic companies, $45.7 \%$ of examinees think that competitiveness of domestic companies does not satisfy the requirements of international market, $45.17 \%$ of them think that it only partially satisfy these requirements while $5.56 \%$ of examinees think that domestic companies satisfy conditions for achieving competitiveness on international market and only $3.58 \%$ of them think that it satisfies these conditions in a great deal. Considering the degree of innovations of domestic companies the majority of examinees, $46.5 \%$ of them think that domestic companies partially fulfill this factor of competitiveness, $36.95 \%$ of examinees think that domestic companies do not satisfy this factor, 7.68\% think that domestic companies are innovative, while only $8.87 \%$ of the examined consider domestic companies very innovative. The examinees consider the following elements for development of competitive ability of domestic companies most necessary: standardization of business quality (18.67\%), implementation of modern methods and techniques of management $(17.72 \%)$, investment in development of national brands (12.32\%) and buying modern equipment and technology (11.48\%).

\section{CONCLUSION}

Poor productivity always results in bad competitive ability. In long term, competitiveness cannot be increased by financial support to industry but by increasing productivity. The main problem of domestic companies is uncompetitiveness. Domestic companies cannot count on success on international market without implementation of new knowledge and new technologies. Competitors of Serbian companies, both on domestic and international market, are not only companies from developed EU countries but the companies from newly industrialized countries such as China India, Brazil, Mexico, Turkey, etc. The main factor of their success is optimization between prices and quality of products based on permanent productivity improvement.

On the bases of the presented research results it can be concluded that the students oriented towards business and management are aware of the fact that standardization of quality of business and implementation of modern methods and techniques of management represent strategic framework for establishing competitive ability of domestic companies and that competitive ability and level of innovations in domestic companies are on very low level.

Business performance of domestic companies have to be based on implementation of management techniques which support competitiveness, innovations and flexibility as well as on urgent improvement of knowledge of their employees, especially their executives. It is also necessary that our companies free themselves of the old way of thinking limited by domestic market. Global economy involves insecurity. On the other hand it offers enormous possibilities to organizations and individuals who are brave enough to adjust to it. Globalization represents the only way for all transitional countries but it must be insisted on development of industrial production. Newly industrialized countries have worked on 
development of industrial production and offer of their industrial products on the global market.

\section{REFERENCES}

Communication From the Commission to the European Parliament and the Council - Enlargement Strategy and Main Challenges 2012-2013. (2012). from European Commission http://ec.europa.eu/enlargement/pdf/key_documents/ 2012/package/strategy_paper_2012_en.pdf

Đorđević, D., Coćkalo, D., \& Bogetić, S. (2011). Novi model upravljanja i razvoja konkurentske sposobnosti domaćih preduzeća (New Model of Competitiveness Management and Development of Domestic Enterprises). Paper presented at the UASQ ICQ 2011 - International Convention on Quality, Belgrade, Serbia.

From Transition to Transformation Sustainable and Inclusive Development in Europe and Central Asia. (2012). from United Nations Economic Commission for Europe (UNECE) http://www.unep.org/roe/Portals/139/Moscow/FromTransition-to-Transformation.pdf

Ghemawat, P. (2010). Redefiniranje globalne strategije. Zagreb, Croatia: Mate.

Will, M. (Ed.). (2006). Local/Regional Economic Development in South-Eastern Europe - Concepts, instruments, and lessons learned: Deutsche Gesellschaft für Technische Zusammenarbeit (GTZ)
GmbH, Division 311.

Kefela, G. T. (2010). Knowledge-based economy and society has become a vital commodity to countries. International NGO Journal, 5(7), 160-166.

Muldur, U., Corvers, F., Delanghe, H., Dratwa, J., Heimberger, D., Sloan, B., \& Vanslembrouck, S. (2006). A New Deal for an Effective European Research Policy: Springer.

Ohmae, K. (2007). A new global stage (in Croatian). Zagreb, Croatia: Mate.

Porter, M. E. (1990). The Competitive Advantage of Nations. London: Macmillan.

Stajano, A. (2009). Research, Quality, Competitiveness. EU Technology Policy from the Knowledge-based Society: Springer.

The best countries for business. (October 2011). Forbes.

The Global Competitiveness Report 2008-2009... The Global Competitiveness Report 2012-2013. (20092012). from World Economic Forum

Thompson, E. R. (2003). A grounded approach to identifying national competitive advantage. Environment and Planning A, 35(4), 631-657.

Thompson, E. R. (2004). National competitiveness: A question of cost conditions or institutional circumstances? British Journal of Management, 15(3), 197-218.

Yu, X., \& Wang, W. (2010). Study on Export-oriented Enterprises' Improvement of Competitive Capacity Based on Cost Advantage. Journal of Management and Strategy, 1(1), 188-122. 